\title{
A Semantic Model of Multiple Space of Role and State (I)
}

\author{
Huang Ziyou*
}

\begin{abstract}
Language artificially classifies the varied phenomena of the chaotic world into four kinds of expressions: "real displacements", "real shifts", "virtual displacements" and "virtual shifts". This paper is mainly a semantic exploration of the "real displacements" and the achievement of the discussion is a foundation for the semantic study of the latter three kinds of expressions. Emphasis will be laid upon the verbs and their relationship with nouns. The "multiple space role-state-ring-chain" model designed in the paper is aimed at delving beneath the surface of a verb and studying its inner micro-world, so as to grasp the transformational rules among the surface, deep and underlying structures of a sentence and to promote the discovery for the mystery of human languages.
\end{abstract}

Keywords: role, state, ring, chain, space, real entity, displacements

\section{Introduction}

In the theories of the semantic cases of Fillmore's case grammar and Chomsky's thematic roles, every verb which exists in a specific language condition is in principle regarded as a whole when the semantic and syntactical relations between noun (phrase) and the verb are discussed. This paper proposes a theory of "the multiple space role-state model", and gives a comprehensive analysis and description of the semantic meaning, grammar and pragmatics of a sentence in order to penetrate the surface of a verb and to study its inner micro-world, to grasp the transformational rules among the surface and the deep and underlying structures of a sentence and to further our understanding of the mystery of human languages.

This model mainly consists of four essential elements: the role, the state, the ring and the chain, which are to be respectively discussed below.

\section{Roles}

The Ergative Role and the Mover Role both are generally named "real entity roles", and all the roles in space are called "Space Roles".

Real entity refers to a particular meaning item of a noun. It moves continuously in space

\footnotetext{
${ }^{*}$ Huang Ziyou: Department of Chinese Literature and Language, Jiangsu Education Institute, 4-1804 , Moonlight Plaza , Nanjing 210036, Jiangsu , China. E-mail:familyalbum_2004@sina.com. 


\section{Huang Ziyou}

and the movement consists of two kinds of motions, one simple and one complex.

The process of a theoretical simple movement is a semantic ring which includes the Role and the State (see 2 State). The role consists of two kinds of Real Entity Roles: Mover Roles and Ergative Roles, and of five kinds of Space Roles: Ergative-Circumstance Role, Mover-Circumstance Role, Circumstance Role, Linear Role and Periphery Role. The Linear Role can be subdivided into seven Space Roles; they are the Source Role, the Departure Role, the Way Role, the Arrival Role, the Terminal Role, the Goal Role and the Orientation Role.

A complex motion consists of two or more simple motions, which is called a semantic chain.

Special attention is requested here: the Mover Roles and Ergative Roles in the following paragraphs (1.1.1. and 1.1.2.) are further classified into special roles brought forth by the special pragmatic focuses and by the special semantic relationship produced when various semantic rings in the semantic chain of the complex motion are combined one after another; and each special role is essentially either Ergative Role or Mover Role.

\subsection{Real entity roles}

\subsubsection{Mover role}

An entity that can move or is moving is considered to take the Mover Role. In Ex 1, the dynamic of the verb "diào " takes "Lao Wang" in the Mover Role. The word here means "fall", which is a part of speech on the surface level of discourse and "dynamic" a particular meaning item of the word. In this sense it means "to fall from high to low", which we name "diào-1". And we can identify other items of meaning accorded to the word "diào", such as "to fall behind", "to get rid of", "to leave", "to swing", "to turn round" and so on. We put them into "diào-2", "diào-3", "diào-4", "diào-5", "diào-6" and so on. Only in a context can we understand the accurate meaning of the verb "diào".

(1) Lăo Wáng diào jìn hú zhōng .

Lao Wang fall into lake middle

(老王掉进湖中。/ Lao Wang fell into the lake.)

"Lao Wang" is playing two roles in this sentence: Ergative Role (see 1.1.2 Ergative Role) and Mover Role. In the Ergative Role, Lao Wang is regarded as a man, and in the Mover Role, Lao Wang is a moving thing, a body or something like "ball", "book", "cup". "Diao" is the dynamic of Mover Role. The "hu" (lake) takes the Goal Role with the meanings of the surface, the inside and the bottom of the lake. The "jin...zhong"(into) is the role marker of the Goal Role.

The Mover Role consists of two roles, the Intermediary Role and the Theme Role. The Intermediary Role is a medium with which Ergative Role exercises influence on the Theme Role. The Intermediary Role is called Instrumental Role when it matches with the Agent 
Role of the Ergative Roles (see "1.1.2 Ergative Role). The Instrumental Role includes the instruments in its general sense (like the "key" in Ex 2), the motive force (like the "motive force" in Ex 3), the carrier (like the "paper" in Ex 4), the credentials (like the "evidence" in Ex 5), and the manner (like the "Constitution" in Ex 6) and so on. The Intermediary Role is called the Cause Role when it matches with the Create-Matter Role of the Ergative Roles and it is the medium of the Theme Role affected by the Create-Matter Role when it creates motion. The Cause Role, for instance, in Ex 7 is latent "huge energy."

(2) Tā yòng yàoshi kāi-le mén .

He with key open-ed door .

(他用钥匙开一了门。/ He opened the door with the key.)

(3) Jīdújiào jùyǒu ràng xǔduō rén qiánchéng de dongli Christianity have let many people god-fearing of motive force

(基督教具有让许多人虔诚的动力。/ Christianity has the motive force of making many people God-fearing.")

(4) Tā juédìng bă xiăngfã xiě zài zhǐ shàng .

he make up his mind Pre-O ${ }^{\mathbb{1}}$ ideas write on paper surface

(他决定把想法写在纸上。/He made up his mind to write down his ideas on the paper.)

(5) Gēnjù zhēngjù shīqù-de cáichăn yòu huán-gěi-le tāde suǒyǒurén . according to evidence lost property again returned its owner

(根据证据, 失去一的财产又还-给-了它的所有人。/ The lost property is returned to its owner according the evidence.)

(6) Wǒmen yángé ànzhào xiéhuì zhāngchéng bàn shì .

we strictly according to association constitution handle affairs

(我们严格按照协会章程办事/ We shall act strictly according to the “Association Constitution". )

(7) Léidiàn bă băinián dà shù pīkāi-le .

thunder and lightning Pre-O hundred-year-old big tree split

(雷电把百年大树䢃开-了。/ The thunder and lightning split the hundred-year-old big tree.) (2)

Theme Roles can be classified into two categories, namely variation and the non-variation. The variation category can be divided into the displacement and the shift types. The displacement type, in turn, can be subdivided into whole movement and

\footnotetext{
(1) "Pre-O" means that the Chinese preposition "bă" is followed by an object of clause.

(2) The above sentence is synonymous to the following:

Léidiàn yòng zijǐde jùdà néngliàng bă băinián dà shù pǐkāi-le. hunder and lightning with its own huge energy Pre-O hundred-year-old big tree split

(雷电用自己的巨大能量把百年大树䢃开-了。/ The thunder and lightning split the hundred-year-old big tree with its own huge energy.)
} 


\section{Huang Ziyou}

appearance-disappearance. The shift type can be subdivided into partial change, creation \& extinction, and gathering \& scattering. The non-variation category can be subdivided into the involvement, the stop and the virtualized. The involvement can be subdivided into involving space, involving object and experiencing. The stop can be subdivided into the control and the stillness. The virtualized ${ }^{3}$ can be subdivided into the division, the possession, the explication and the existence.

The classification is shown in the follows diagram (Huang, 1996):

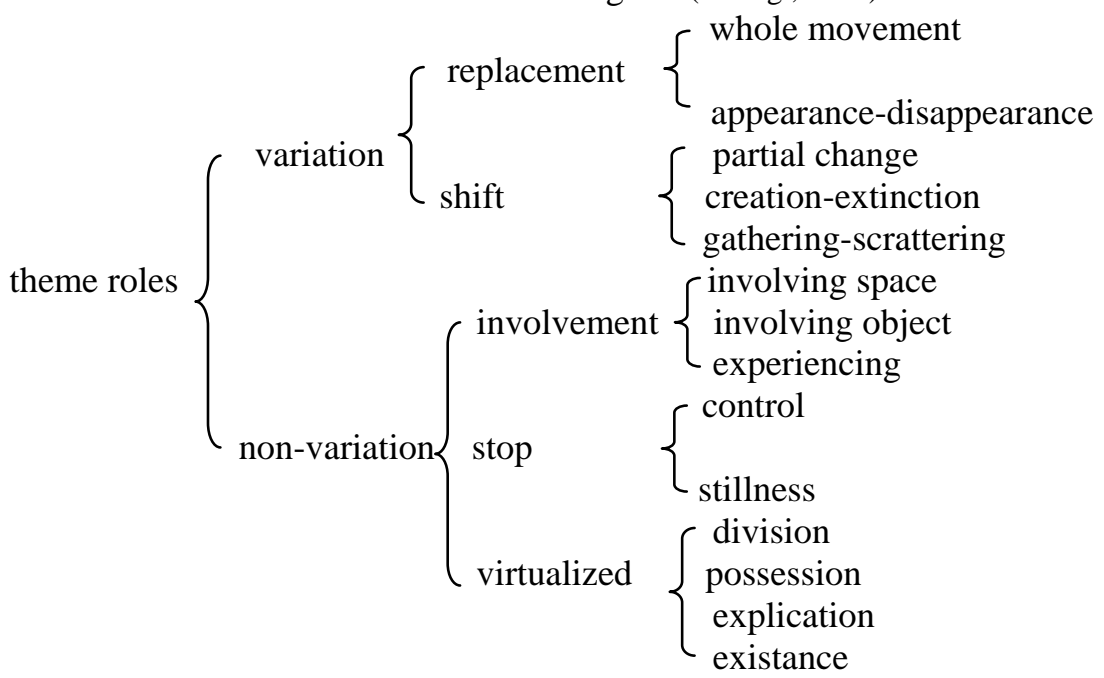

According to the above 14 classes, the Theme Role can be subdivided into 36 roles.

The Whole Movement ${ }^{\oplus}$ contains 4 roles: the Displacement Role, the Transmission Role, the Exchange Role and the Interaction Role. The Displacement Role is the simplest role of the Whole Movement. It often needs Intermediary Role. Taking Ex 8 for instance, the sentence contains the meaning of "coming on foot", and the "foot" takes the Instrumental Role. The important feature of the Transmission Role is that its dynamic always appears in pairs, like "giving" and "receiving". The "book" in Ex 9 is Transmission Role. The Exchange Role involves two-way transmission. The two parties can be both realized, as in Ex 10, or either party is realized. The sentence "He teaches me English", for instance, implies "I learn English from him", the former is realized and the latter not. The Intermediary Role in the Interaction is "pronunciation organ", as it is in Ex 11. When you "talk", you would use your mouth, so "mouth" is the Interaction Role, and what you said is the Mover Role, which is the not realized Interaction Role.

(8) Mén kāi-le, Xiăo Liú zǒu-le jìnlái.

(3) Virtual verbs are “有”、“在”、“是”、“为” and zero virtual forms of logical connection.

(4) A MOVER is regarded as a whole whose internal movement and change are often neglected. 


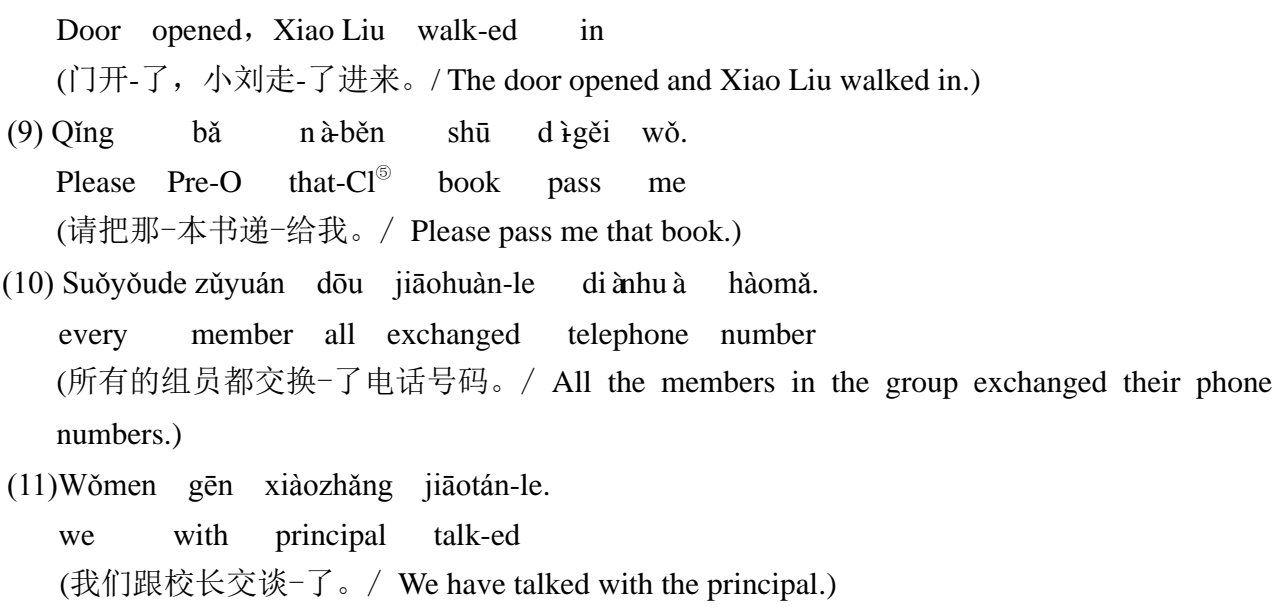

The Appearance-Disappearance contains 2 roles, the Appearance Role and the Disappearance Role. The Appearance Role (like the "blood" in Ex 12) and the Disappearance Role (like the "ship" in Ex 13) are a pair. They are the opposite conversion of presence and absence. Appearance Role is absence converted to presence and Disappearance Role presence to absence. Appearance Role and Disappearance Role are in turn opposite to the four roles mentioned above, which are perceived by the senses.

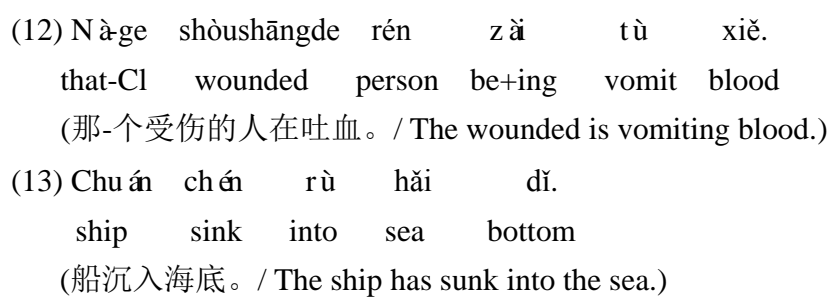

The Partial Change contains 4 roles: the Transfiguration Role, the Metamorphosis Role, the Ingestion Role and the Detachment Role. The Transfiguration Role is a Mover Role that has changed its own shape, sometimes changing beforehand, sometimes afterwards. In Ex 14, the Mover Role "map" is "spread" before its change and "folded" afterwards. The Metamorphosis Role is a Mover Role that has changed its state, but has not become something else, sometimes changing beforehand, sometimes afterwards. In Ex 15, the window frame is rotten, but it is still a window frame. The Ingestion Role and the Detachment Role are a pair of Mover Roles. Ingestion Role is a role with a little of attached or absorbed matter. In Ex 16 “cream' is the absorbed matter. Detachment Role denotes what is attached to or absorbed in by the Mover Role is removed, like the "blood" in Ex 17.

(14) Tā bǎ dìtú zhédié qǔlai, fàng jìn -le kǒudài.

(5) "-Cl" means the Chinese classifier. 


\section{Huang Ziyou}

he Pre-O map fold up, put into -ed pocket

(他把地图折叠起来, 放进-了口袋。/ He folded the map and put it into his pocket.)

(15) Chuāngkuàng y̌̌jīng wánquán làn diào -le.

window frame already completely rot away -ed

(窗框已经完全烂掉了。) (“The window frame is completely rotten.”)

(16) Zhè-zhǒng rǔshuāng róngyì xīshōu dào pífū li.

this-Cl cream easily absorb into skin inside

(这-种乳霜容易吸收到皮肤里。/ This kind of cream will be easily absorbed by your skin.)

(17) Tā bă LǐMíng liăn shàng de xiě xǐdiào-le.

he Pre-O Lǐ Míng face surface of blood washed

(她把李明脸上的血洗掉了。/ She washed the blood from Li Ming’s face.)

The Creation-Extinction consists of 2 roles: the Creation Role, and the Extinction Role. Creation Role means creating something from nothing, as in Ex 18: two children are "created". Extinction Role is to change something into nothing. For instance, in Ex 19 the lights went out.

(18) Tā wèi Lăo Zhāng shēng-le liăng-ge háizi.

she for Lăo Zhāng give-ed birth two-Cl children

(她为老张生-了两-个孩子。/ She gave birth to two children for Lao Zhang.)

(19) Suǒyǒude dēngguāng dōu xīmiè -le.

all lights (all) go out -ed

(所有的灯光都熄灭了。/ All the lights went out.)

The Gathering-Scattering contains the Gathering Role and the Scattering Role. The Gathering Role refers to something new after its gathering a few things together. For instance, in Ex 20 "dispatching note" and "invoice" are pinned together and become a combination, but there is no new name for it. In contrast, "to build a house", the house is a new thing with a new name. Scattering Role is a role to turn something into several things after the change. For instance, in Ex 21 the loaf is divided into "four thick pieces", and there is no new name for it.
(20) Bă fāhuòdān ding zài fāpiào shang.
Pre-O dispatching note pin to invoice surface
(把发货单订在发票上。/ Pin the dispatching note to the invoice. )
(21) Tā cóng nà-kuài miànbāo shang qiē-xià 4 hòu piàn.
he from that-Cl loaf top cut 4 thick piece

(他从那-块面包上切下四厚片。) (“He cut four thick pieces from the loaf.)

The Involving Space contains 4 roles: the Containing Role, the Attaching Role, the Enclosing Role and the Mantling Role. The Containing Role is a role with a space or a container. The space or the container is not changeable. For instance, the Containing Role 
"tank" in Ex 22 is not changeable and the Displacement Role "gasoline" is changeable. The Attaching Role is a role with a much bigger space, to which something else is attached, like the "hook' in Ex 23. The "coat" is changeable as the Displacement Role. Enclosing Role is a role with a space surrounded by something. The "hedge" in Ex 24 is in the Enclosing Role while the "parterre" is in the Aim Role. There is a space between the parterre and the hedge. The dynamic "enclose" contains two stages, the "process" and the "result". The process stage is Variation Role which we name "enclosing-course" and the result stage is Non-Variation Role which we name "enclosing-result", as in this example. The Mantling Role is a role with something covered by something else. Usually there is no space between them and they touch each other directly. The "newspaper" in Ex 25, for instance, is the Mantling Role, and the "floor" a Touch Role.

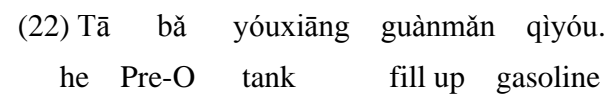

Involving object contains 2 roles; the Aim Role and the Touch Role. The Aim Role is the object at which the dynamic is aiming. It is not changeable, but something behind it is, like a person's body or a part of the body, or something else. In Ex 24, the "parterre' is the Aim Role and the "hedge" is the Enclosing Role. The course of the enclosing is changeable (compound role). The Touch Role is the object which is touched by a dynamic action. It is not changeable itself, but the result of the touching maybe changeable. For instance, in Ex 25 the "floor" is Touch Role. In the expression "beat him", "him" is Touch Role and there is no mention of the result. If you want to express the result, another dynamic verb is needed. For instance, in the expression “dă shāng tā (打伤他, contused him)", the object of the compound dynamic action "him" is both Touch Role and Metamorphosis Role. Roles change and it is also the Multiple Role mentioned in the title of this paper. (Huang, 1985, 1994)

The Experiencing consists of 5 roles: the Feel Role, the Perception Role, the Sensibility Role, the Obtainment Role and the Loss Role. They are all the objects of the action 


\section{Huang Ziyou}

"experience", and their subjects are not Ergative Roles, but Metamorphosis Role, Extinction Role and so on, like the Feel Role "Xiao Han' in Ex 26. The dynamic verb "kàn (look)" is "looking-course" of an action and the verb "kànjiàn(see)" is the result of the action. It belongs to non-variation. Ex 26 is an instance of one sentence with two verbs to express the two action-stages. The experiencing "she" gets the visual information and is Metamorphosis Role. The "wèntí(problem)" in Ex 27 is Perception Role and the subject "she" is a Metamorphosis Role getting information upon her pondering. The "nǐ (you)" in Ex 28 is a Sensibility Role and the subject "wǒ (I)" is a Metamorphosis Role since I have increased my emotions in the experience. The "wàitào(coat)" in Ex 29 is an Obtainment Role. The subject "tā (he)" is a Metamorphosis Role because he has got the right of thing from the action of buying and also an Ergative Role because "he" is the agent of the action of buying. "He" here plays the multiple roles - both Metamorphosis Role and Ergative Role. The "wàitào(coat)" in Ex 30 is a Loss Role. The subject "tā (he)" is a Metamorphosis Role since he has lost the right of thing through the action of selling and he is also an Ergative Role for he is the agent of the action of selling. "He" here is another example of multiple role (Huang, 1985, 1994).

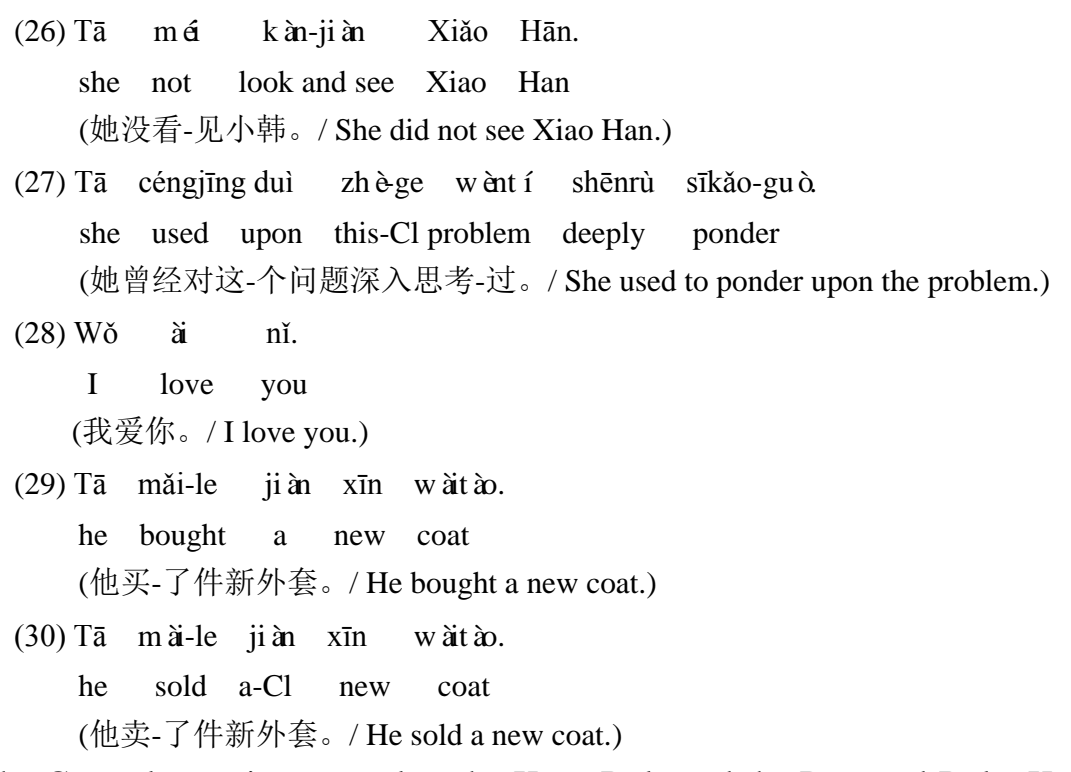

The Control contains two roles: the Keep Role and the Deterred Role. Keep Role keeps the characteristics of a Mover Role. The "mùcái(wood)" and "pígé(leather)" in Ex 31 are Keep Roles. The "shàngguānglà (polishing wax)" is a Create-Matter Role and the protecting elements are its covert Origin Role. Deterred Role denotes that the characteristics of a Mover Role are unable to be changed though they want to or are to be deterred when they were changing. Taking Ex 32 for instance, the action of the "qīnluèjūn 
(invaders)" was deterred owing to the "dǐkàng (resistance)". The "qīnluèjūn (invaders)" is a Deterred Role.

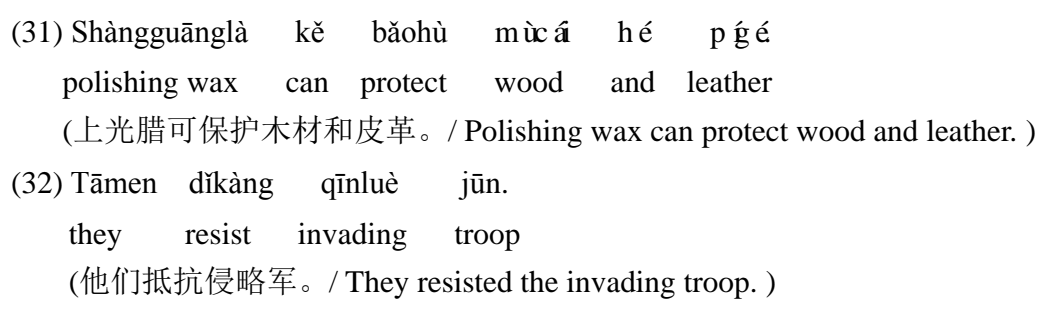

The Stillness contains 2 roles: the Termination Role and the Nature-Manner Role. The Termination Role refers to the Theme Role involved in the result stage after the dynamic course. The "qìchē(car)" in Ex 33 is a Termination Role. The action "tíng (stop)" is "stop-result" in the sentence. The word "ting" is polysemic, we write "tíng-result" as "tíng1" and the action to stop something as "tíng2". The "tíng1" implies the result stage of an action and the "tíng2" the process stage of an action. The Nature-Manner Role is the Theme Role to which a static adjective is attributed. The static state is a special dynamic state. The word "ěr(ear) "in Ex 34, for instance, is a Nature-Manner Role, the "yīnyuè(music)" is the Create-Matter Role and its recessive Origin Role is something pleasing to the ear.

(33) Qìchē zài jiāotōngdēng qián tíng-le-xiàlai.

(汽车在交通灯前停-了下来。/ The car stopped at the traffic lights.)

(34) Yīnyuè hěn yuè ěr.
Music very pleasing ear

(音乐很悦耳。/ The music is very pleasing to the ear.)

The division contains 2 roles - the entirety role and the part role. The entirety role means the explanatory whole, and in Ex 35 "dăng"(Party) is the entirety role. The part role means each part of the explanatory whole, and in Ex 35 "dăngyuán"(Party members) is the part role .

(35) Zhè-ge dăng zài 1999 nián yōngyǒu shí wàn dăngyuán
This-Cl party in 1999 year had 100,000 members
(这-个党在 1999 年拥有十万党员。 / In 1999 the party had 100,000 members .)

The possession contains 2 roles - the owner role and the owned role. The owner means the possessor. We use the virtualized dynamic verb which is different from the obtainment role with the general dynamic verb, and in Ex 36 "tâ"(he) is the owner role. The owned role means the possessed thing of the possessor, and in Ex 36"chē" "is the owned role .

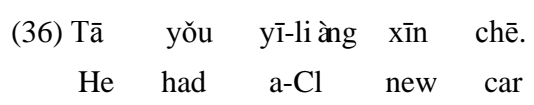


(他有一-辆新车。/ He had a new car .)

The explication role contains 2 roles - the explicandum role, and the explicans role. The explicandum role means the explained thing or person, as in Ex 37 "Zhāng Huá " is the explicandum role, which is the explained person. The explicans role means explanatory contents, as in Ex 37 "yīshēng" is the explicans role .

(37) Zhāng Huá shì wèi yīshēng.
Zhang Hua is a-Cl doctor

(张华是位医生。/ Zhang Hua is a doctor .)

The existence contains 2 roles - the existent role and the location role. The existent role means the person or thing which exists, as in Ex 38 "yóuyǒngchí" (swimming pool) is the existent role (entity). The location role means the place in which the person or thing exists, as in Ex 38 "fàndiàn" (hotel) is the location role (space). Actually, the entity and the space can be converted into each other (Huang, 1985). "fàndiàn "(hotel) will become an entity in a larger space, such as “这条街上有饭店吗?”(“Is there a hotel in the street?”). "yóuyǒngchí" (swimming pool) can also change into a space in a smaller entity, such as “游泳池里有游泳者吗? ”(“Is there a swimmer in the swimming pool?”)
(38) Fàndiàn li yǒu yóuyǒng chí ma ?
Hotel inside have swimming pool Pcl-question ${ }^{(}$
(饭店里有游泳池吗?/ Was there a pool at the hotel?)

\subsubsection{The ergative role}

The self-controlled persons and the personified (crowd, organizations, animals, natural force, ghosts and gods etc.) who cause Movers to move or change are called the ERGATIVE role .

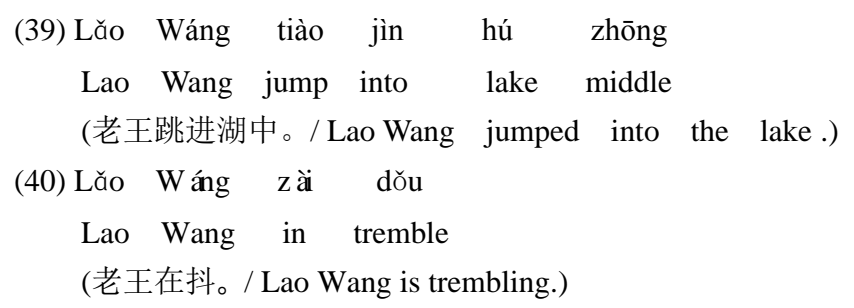

In Ex 39, the dynamic "Tiào" implies that firstly "Lăo Wáng" is an ERGATIVE, and the act of "tiào" is an action which "Lăo Wáng" deliberately takes and "Lăo Wáng" is also a Mover who himself is regarded as a mere moving Entity fallen into the lake. So in the sentence, "tiào" implies "cause...fall" and the whole sentence means "The ERGATIVE Lăo Wáng causes mover (=the ERGATIVE-self as a pure body) Lăo Wáng to 'fall' into the lake". The dynamic "tiào" can be written as "tiào-ergATIVE- MOVER (tiào-ERGATIVE- MOVER)",

() "Pcl" means the Chinese particle. 
and the dynamic "diào "can be written as "diào-MOVER (diào- MOVER )".

The person or animal can have two kinds of meaning in a certain motion - (1) just a MOVER, such as the Ex 1 "diào- MOVER", and (2) an ERGATIVE and a MOVER concurrently, such as the Ex 39 "tiào-ERGATIVE- MOVER". TWO kinds of meaning involve TWO different dynamics. But there is ONE dynamic for TWO kinds of meaning, and it depends on the context, without which there will be ambiguity. In Ex 40 "dǒu" is a dynamic which is ambiguous. The first meaning is "dǒu -MOVER", and "Lăo Wáng" is the MOVER; his body cannot help but "tremble", the reason being that "Lăo Wáng" fears, or gets sick, etc. The second meaning is "dǒu -RERGATIVE-MOVER", and "Lăo Wáng " is the ERGATIVE, who deliberately does an act of "dǒu", such as "Lăo Wáng" puts on a show, but his body trembles, as a result "Lăo Wáng" is a MOVER too.

The ERGATIVE role can be divided into 2 types - the agent role and the create-matter role (Huang, 1996).

The agent role means the persons and things who deliberately cause Movers to move or change.

The agent role can be subdivided into 2 types - the single agent role and the co-operating agent role. The single agent role means a single agent unit (an individual person, a group, etc) can complete a particular dynamic action, as in Ex 41 "tà "(she).-Certainly, the completion of the behavior "chī "can also involve many people, but it essentially only involves a person. The co-operating agent role is the agent role that several single agent units (persons, groups, etc) must be engaged in the common activity and must co-operate to complete a particular dynamic action. Every member of them is called the branch agent role-N ( $\geq 2$ ), e.g. in Ex 42 "tā" (she) is just the bride, namely, "qīzi "(wife) who gets "jiéhūn"(married), and "tâ" (she) is the branch agent-1. So she has a groom, namely, "zhàngfu "(recessive husband) who is the branch agent-2. Both have to exist. The co-operating agent roles can also appear together, such as Ex 43 and Ex 44.

The create-matter role means the natural things which cause Movers to move or change, such as "gēshēng"(songs) in Ex 45 .

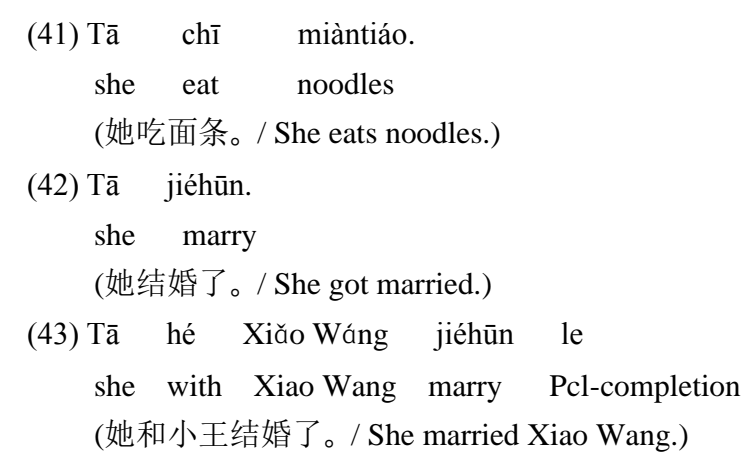


Huang Ziyou
(44) Tāmen jiéhūn le .
they marry Pcl-completion
(他们结婚了。/ They got married.)
(45) Tāde gēshēng qīngdăo-le suǒyǒu zàichăngde guānzhòng .
her song infatuate-ed all present audience
(她的歌声倾倒-了所有在场的观众。/ Her singing has infatuated the whole audience.)

The agent role can also be subdivided from the other perspectives, such as (1) the independent agent role and (2) the control agent role. The latter includes the controlling agent role and the controlled agent role .

(46) Tā gài-le fángzi .

(他盖-了房子。/ He built a house . (a) He built a house by himself. (b) He was made to build a house. (c)He had a house built.)

Because in Ex 46 there are the different roles which "tā" (He) plays, as a result there is ambiguity. The sentence may mean that "tā "himself has finished to build a house, so "tā" (He) is the independent agent role in meaning (a). It also means that there can be a "Lao Wang" who hired "tā "(him) to build a house, so "tā" (him) is the controlled agent role in meaning (b), and covert "Lao Wang" is the controlling agent role here. People will say, "Lao Wang has built a house." The third possibility is that "tā "(he) has hired some persons to build a house, so "tā"(he) is the controlling agent role in meaning (c).
(47) Nánjīng jiànzào-le Chángjiāng Dà Qiáo.
Nanjing build-ed Yangtze River big Bridge (the controlling agent role)
(南京建造-了长江大桥。 / Nanjing has built the Yangtze River Bridge .)
(48) Tā zào-le mén qián de xiăo qiáo.
he built-ed door front Pcl-of small bridge (the independent agent role)
(他造-了门前的小桥。/ He built a small bridge in front of the door .)

In Ex 47 "Nanjing" is a personified thing which means Nanjing government and people (the controlling agent role) who hired a large group of builders (the controlled agent role) to construct the Yangtze River Bridge. We may say: "In Nanjing a Yangtze River Bridge has been constructed." to mean "Nanjing" only as the Space role, or the controlled agent role and the branch agent role, because the Bridge was constructed by China, which is the controlling agent role. In Ex 48, the overwhelming possibility is that "tā "(he) is only the independent agent role .

\subsubsection{The correlation between the ERGATIVE and the MOVER}

The motion of the ERGATIVE and the MOVER must have a particular verb in the surface structure, such as the MOVER verb "diào"(fall) in Ex 1 and concurrent ERGATIVE and MOVER verb "tiào"(jump) in Ex 39. In the surface structure, the 
MOVER is an obligatory role, and the ERGATIVE is an optional role, but in the underlying structure, both are obligatory. In Ex 1, "diào " takes "Lăo Wáng" as the MOVER, not the ERGATIVE, but there must be some ERGATIVE. Then what is the obligatory ERGATIVE? It is the personified natural force (Lao Wang may have carelessly slipped down). Or it is the "ghost" as the folkways have it. Then the whole sentence means: "The ERGATIVE natural force (or ghost) causes the MOVER "Lao Wang" who is purely a body to "diào"(fall) into the lake. Or it is some ergative (suspected murderers). Then the whole sentence means: "The ERGATIVE some person causes the MOVER "Lao Wang" who is purely a body to "diào" (fall) into the lake.

When the ERGATIVE (agent role here) causes the MOVER to move or change, the MOVER can be divided into 3 types correspondingly - the full internal MOVER, the partial internal MOVER and the external MOVER. The full internal MOVER means the ERGATIVE and the MOVER as the same person, such as in Ex 50 "rén" (person) is the ERGATIVE and the MOVER concurrently, i.e. the person as the ERGATIVE sends out a motive power, and the same person (whole body) can be regarded as the moving or changing MOVER at the same time. The partial internal MOVER means the ERGATIVE is the whole and the MOVER is a part of same person, as in Ex 50; firstly, "rén" is the ERGATIVE and the MOVER concurrently, i.e. the person as the ERGATIVE sends out a motive power, and the same person (whole body) can be regarded as the moving or changing MOVER. However, the same person's legs are moving back and forth, so they are the partial internal MOVER here, though it is recessive. The external MOVER means that the ERGATIVE and the MOVER is entirely separable, namely, the MOVER is outside the ERGATIVE's body, as in Ex 49, "yàopiàn"(pills) is an external MOVER .

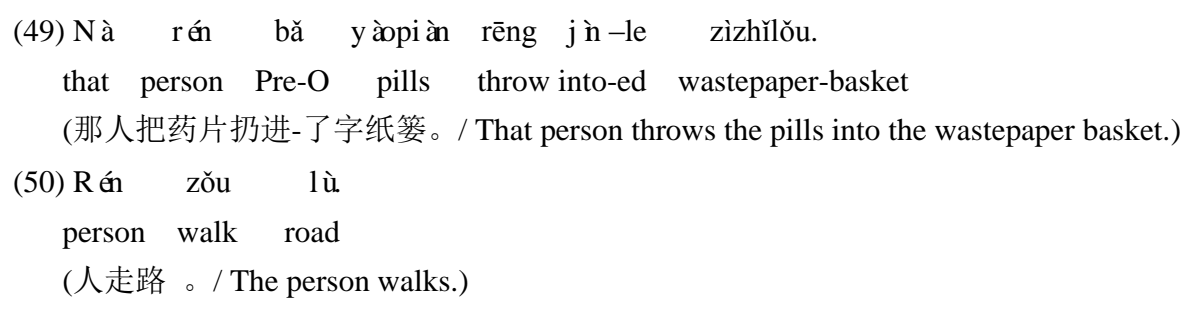

The internal MOVER is either full or partial. A person's action necessarily starts from a part of the person. If one takes a pen, one uses one's hand. If one kicks a ball, the person uses his foot. If one eats, the person uses his hand to send food into his mouth. If he watches television, the person uses his eyes. The above-mentioned verb dynamic means an ERGATIVE must first use the internal MOVER, then the internal MOVER makes the external MOVER move or change. But in the actual discourse, if people do not emphasize, the internal MOVER is usually recessive.

\subsection{The space roles}




\section{Huang Ziyou}

The Space Roles means the SPACE in which the MOVER and the ERGATIVE exists or moves in a theoretically simple motion process. The Space Roles are divided into 5 kinds - (1) the ergative-circumstance role, (2) the mover-circumstance role, (3) the circumstance role, (4) the linear role and (5)the periphery role. (Huang, 1994)

\subsubsection{The ergative-circumstance role}

The ergative-circumstance role means the SPACE in which the ERGATIVE exists or moves, in Ex 51, "tóngxuémen" (students) is the ERGATIVE, "Yīngyŭ" which means "the English exam" is the metamorphosis role. All the students are in the classroom, which is the ergative-circumstance role and its role marker is "zài...li " (inside).

$\begin{array}{cccccc}\text { (51) Tóngxuémen } & \text { zài } & \text { jiàoshì } & \text { li } & \text { kăo } & \text { Ȳ̄ngyǔ. } \\ \text { students } & \text { in } & \text { classroom } & \text { inside } & \text { examine } & \text { English }\end{array}$

(同学们在教室里考英语。/ The students took an English exam in the classroom.)

1.2.2. The mover-circumstance role

The mover-circumstance role means the SPACE in which the MOVER exists or moves; in Ex 52 "zì"(words) is the MOVER (external MOVER), and "lăoshī "(teacher) is the ERGATIVE. "hēibăn"(blackboard) is the space role, because the words which "lăoshī " writes is all on it, but "lăoshī "is NOT on it, so it is the mover-circumstance role instead of ergative-circumstance role. The role marker is "zài...shàng"(on). This is an analysis by default. It is possible that "hēibăn" is placed levelly on the ground, "lăoshî" stands on "hēibăn", and "zì" are written on this "hēibăn", or written in other places, e.g. written on a notebook held by "lăoshî" or on a wall by the side of "lăoshî". Here in Ex 52 "hēibăn" is the ergative-circumstance role of "lăoshì", and the notebook or wall is just the mover-circumstance roles of the "zì".

$\begin{aligned} & \text { (52) Lăoshī zăi hēibăn shàng xiě zì. } \\ & \text { teacher } \text { on blackboard top write words }\end{aligned}$

(老师在黑板上写字。/ The teacher writes the words on the blackboard.)

\subsubsection{The circumstance role}

The circumstance role means the larger space which contains the ergative-circumstance role and the mover-circumstance role. The ergative-circumstance role can be different from the mover-circumstance role, but both usually occupies the same larger space-the circumstance role. In Ex 53 the ergative-circumstance role is "Zhāng Bóshì's" chair (he sits in it) and desk (his arm is on it). The mover-circumstance role is the computer screen on which words of "lùnwén" are displayed. So the chair, the desk and the computer screen entirely is in the larger space "shüfáng", which is a circumstance role.

(53) Zhāng Bóshì zài shūfáng li xiě lùnwén.

Zhang Doctor in den inside write dissertation

(张博士在书房里写论文。/ Doctor zhang is writing a dissertation in the den.) 


\subsubsection{The linear role}

The linear role means the linear track in which the MOVER moves or changes. In Ex 54, "Liú Fēi "is the ERGATIVE and the full internal MOVER concurrently. One will also say: "Liu Fei ran 5000 meters in Shanghai (or the stadium)", here Shanghai (or the stadium) is a mover-circumstance role. But according to the normal sports regulations, "Liú Fēi "has to finish on some running track (or some route ) - totalling 5000 meters, so this track (or this route) is the accurate part of the mover-circumstance role, i.e. the linear role. In this sentence, the role marker is recessive. Under the other conditions, the role markers can be “沿着(yánzhe, along)”, “从(cóng, from )... 到(dào, to)”etc.

$$
\begin{aligned}
& \text { (54) Liú Fēi păo wán-le } 5000 \text { mǐ. } \\
& \text { Liu Fei ran finish -ed } 5000 \text { meters } \\
& \text { (刘飞跑完-了5000米。/ Liu Fei ran } 5000 \text { meters.) }
\end{aligned}
$$

According to the sequence and characteristics of the motion of the MOVER, the linear roles can be classified into 7 types - the source role, the departure role, the way role, the arrival role, the terminal role, the goal role and the orientation role. The location of the MOVER before it sets out is called the source role. It is possible that the source role is the terminal role of the last Ring-Chain, such as in Ex 55 "ménkǒu" is the source role, its role marker is "zài". The departing place and the starting place are called the departure role. The source role and the departure role are the same place, such as in Ex 56 "ménkŏu" is the departure role, and its role marker is "cóng". The way between the source role and the terminal role is called the way role. Sometimes the whole course of the way role is mostly recessive and the speaker emphasizes some representative spatial points - the representative way role, e.g. in Ex 61"xīliú"is the way role, only the representative way role, with the way role before and after the "xîliú" recessive. Its role marker is “沿着 (yánzhe, along)”、“通过(tōngguò, via)”““经过(jīngguò, through)”, etc. The place to which the MOVER moves or changes is called the arrival role, as in Ex 57 "miànqián" (front) is the arrival role, often the same thing as terminal role. The static stopping place of the MOVER is called the terminal role, as in Ex 58, "miànqián" is the terminal role, and its role marker is "zài". The expected aim of the motion of the MOVER is called the goal role, as in Ex 59 "wǒ" is the goal role, and its role marker is "xiàng", "cháo", "lái", "qù", etc. The motion direction is the orientation role. It is NOT an exact goal or terminal place, as in Ex 60 "yuănfāng" is the orientation role, and its role marker is "xiàng", "cháo", "lái", "qù", etc.

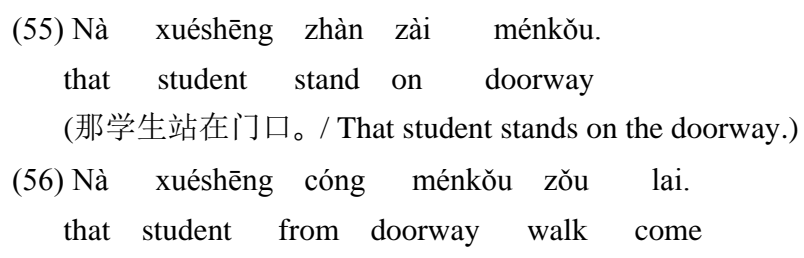


Huang Ziyou

(那学生从门口走来。/ That student walks from the doorway .)

(57) Nà xuéshēng zǒu dào wǒ miànqián.

that student walk to my front

(那学生走到我面前。/ That student walks to the front of me.)

(58) Nà xuéshēng zhàn zài wǒ miànqián.

that student stand in my front

(那学生站在我面前。/ That student stands in front of me .)

(59) Nà xuéshēng xiàng wǒ zǒu lai.

that student toward me walk come

(那学生向我 走来。/ That student walks toward me.)

(60) Nà xuéshēng xiàng yuăn fāng bēn qu.

that student toward far place rush go

(那学生向远方奔去。/ That student rushes toward the very far place.)

(61) Nà xuéshēng tāng-guo xīliú bēn jìn-le mìlín.

that student wade-ed rivulet rush into-ed thick forest

(那学生趟-过溪流奔进-了密林。/ That student waded through the rivulet to rush into the thick forest .)

\subsubsection{The periphery role}

The mover-circumstance role minus the linear role is the periphery role, which is very important too, because many concurrent rings are situated in this space. In Ex 62 "Lĩ Yīng" is the ERGATIVE, and "yòu shŏu"(right hand) is the partial internal MOVER, "hòupái"(rear row) is the mover-circumstance role. The linear track of the motion of "yòu shǒu "- the linear role is Li Ying's right hand - started from the original place, the right side of the right thigh, past the right side of her body, the right side of her neck and the right side of her head, and arrived at the upper right place over the head after she stretched her right arm. Note: "yòu shǒu" is a focus in the communication, and it belongs to the main ring. The "right arm" is outside the focus, and belongs to the concurrent ring. But along with the movement of "right hand", the "right arm" moved together. The linear role "right arm" cannot be similar to the linear role "yòu shǒu", but it is still inside the mover-circumstance role of "hòupái", i.e. the periphery role or part of the periphery role . The periphery role is often recessive.

$$
\begin{array}{rllllll}
\text { (62)Ľ̌ Yīng zài hòu pái jǔ qi-le } & \text { yòu shǒu. } \\
\text { Li Ying } & \text { in rear } & \text { row raise-ed right hand }
\end{array}
$$

(李英在后排举起右手。/Li Ying raised her right hand in the rear row.)

\subsection{The entity role and the space role mutually transferable}

In fact, the ENTITY roles are necessarily transferable into the SPACE roles or vice versa(cf. 3.6 the transformed rings: "the same-role transformed ring"). Please take a look at 
a Chinese libretto shown in Ex 63a. From the Entity role angle, the ERGATIVE of "ná"(hold) is this young girl and she causes a part of her body the MOVER "shǒu"(hands) to "ná" the dish and the small stick. From the space angle, the dish and the small stick are all in "shǒu li " of the young girl at this time, so we can say the sentences in Ex 63b and Ex 63c. A person uses "shǒu" to "ná", but "shǒu" is the default characteristic, which may be omitted, so we can also say the sentence in Ex 63d .

$$
\begin{aligned}
& \text { (63)a. (Tā) Shǒu ná diér qiāo qĭlai. } \\
& \text { (She) hand hold plate tap Pcl-begin } \\
& \text { ((她)手拿碟儿敲起来。 / (She) is holding the plate to begin to tap it.) } \\
& \text { b. (Tā) Shǒu ná-zhe diér qiāo qǔlai. } \\
& \text { (She) hand hold-ing plate tap Pcl-begin } \\
& \text { ((她)手拿-着碟儿敲起来。 / (She) is holding the plate to begin to tap it.) } \\
& \text { c. (Tā) Shǒu li ná diér qiāo qǔlai. } \\
& \text { (She) hand inside hold plate tap Pcl-begin } \\
& \text { ((她)手里拿碟儿敲起来。 / (She) is holding the plate to begin to tap it.) } \\
& \text { d. (Tā) ná-zhe diér qiāo qǔlai. } \\
& \text { (She) hold-ing plate tap Pcl-begin } \\
& \text { ((她)拿-着碟儿敲起来。 / (She) is holding the plate to begin to tap it.) }
\end{aligned}
$$

In the sentence, the entity of the concrete noun or noun phrase can play different Entity roles concurrently ( see "1.1.1. The Involving object" and "1.1.3." etc.), and the Entity roles are transferable into the Space roles and vice versa. Hence "multiple" and "space" in the title of this paper.

\section{The state}

The particular phase or situation that the ENTITY roles move in the SPACE roles is called the state. (Huang, 1985, 1994) Consequently, a state is a space role with a ERGATIVE or MOVER role plus a role marker which is often represented as an adposition phrase - including a preposition phrase in English and Chinese, as in Ex 64 "zài "(in) and Ex 65 "cóng"(from), and a postpositon phrase, such as a location noun (i.e. postpositon), such as in Ex 66 the locality noun "lî", and in Ex 67 the towards verb "jìn" etc..

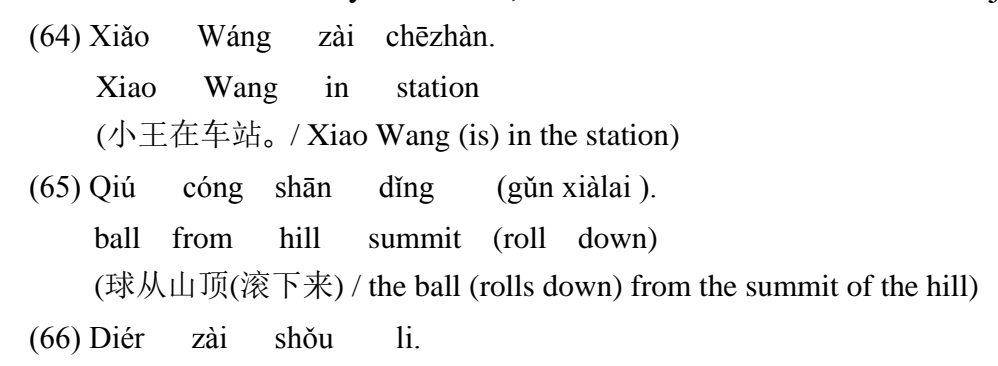


Huang Ziyou

\author{
dish in hand inside \\ (碟儿在手里 / the dish (is) in the hand) \\ (67) xiàngliàn (fàng) jìn shǒutíbāo \\ necklace (put) into handbag. \\ (项链(放)进手提包) / (put)the necklace into the handbag )
}

\title{
2.1. Seven basic states
}

There are 7 kinds of the basic states: (1)the ERGATIVE circumstance state, (2)the ERGATIVE ergative-circumstance state, (3) the MOVER circumstance state, (4) the MOVER mover-circumstance state, (5)the ERGATIVE-MOVER co-circumstance state, (6)the MOVER linear state and (7)the MOVER periphery state.

The state that the ERGATIVE is in the circumstance role is called the ERGATIVE circumstance state, as in Ex 68 "zài bàngōngshì li" (in the office) is the ERGATIVE circumstance state of "bùzhăng"(minister). The state that the ERGATIVE is in the ergative-circumstance role is called the ERGATIVE ergative-circumstance state, as in Ex 69 "zài yǐzi shang"(on the chair) is the ERGATIVE ergative-circumstance state of "bùzhăng". The state that the MOVER is in the circumstance role is called the MOVER circumstance state, as in Ex 70 "zài bàngōngshì li" (in the office) is the MOVER circumstance state of "wénjiàn" (document). The state that the MOVER is in the mover-circumstance role is called the MOVER mover-circumstance state, as in Ex 71 "zài zhuōzi shang" (on the table) is the MOVER mover-circumstance state of "wénjiàn". The state that the ERGATIVE and the MOVER are all in the circumstance role is called the ERGATIVE-MOVER co-circumstance state, as in Ex 72 "zài bàngōngshì li" (in the office) is the ERGATIVE-MOVER co-circumstance state of "bùzhăng" and "zì" (name). The state that the MOVER is in the linear role is called the MOVER linear state, as in Ex 73 "cóng tóu dào jiăo" (from top to toe) is the MOVER linear state of the recessive "the teacher's lines of sight"; "Xiăo Máo" is its MOVER circumstance role. The state that the MOVER is in the periphery role is called the MOVER periphery state, and generally it is regarded as the concurrent ring (see "4. the Ring"), such as in Ex 74"gēbo" (arm) is the MOVER in "tái qi gēbo" (raise his arm), which is only the MOVER periphery state in the concurrent ring.

(68) Bùzhăng zài bàngōngshì li.

minister in office inside

(部长在办公室里。/ The minister is in the office.)

(69) Bùzhăng zài bàngōngshì yǔzi shang.

minister in office chair top

(部长在办公室椅子上。/ The minister sits in the chair of the office.)

(70) Wénjiàn zài bàngōngshì li

document in office inside. 
(文件在办公室里。/ The document is in the office.)

(71) Wénjiàn zài bàngōngshì zhuōzi shang.
document on office table top

(文件在办公室桌子上。/ The document is on the table in the office.)

(72) Bùzhăng zài bàngōngshì li qiān-le zì.

minister in office inside sign-ed name

(部长在办公室里签了字。/ The Minister has signed his name in the office .)

(73) Lăoshī bă Xiăo Máo cóng tóu dào jiăo kàn-le yī-biàn.

teacher Pre-O Xiao Mao from top to toe look-ed one-time

(老师把小毛从头到脚看一了一-遍。/ The teacher looked Xiao Mao from top to toe.)

(74) Tā tái qi gēbo jŭ qi shǒu lai.

he lift up arm put up hand (up)

(他抬起胳膊举起手来。/ He lifts his arm to put a hand.)

The MOVER linear state can be subdivided into 7 ordered States - the MOVER source state, the MOVER departure state, the MOVER way state, the MOVER arrival state, the MOVER goal state, the MOVER terminal state, the MOVER goal state and the MOVER orientation state. The first 5 ordered states form the closed ordered states from beginning to end, and the last 2 ordered states form the open ordered states because they cannot go through to the end.

\subsubsection{Closed ordered states}

The state that the MOVER is in the source role is called the MOVER source state, as in Ex 75 "zài qípán shang"(on the chessboard) is the MOVER source state of "mă(the knight)". The state that the MOVER is in the departure role is called the MOVER departure state, as in Ex 76 "cóng Shànghăi" (from Shanghai) is the MOVER departure state of "huǒchē" (the train). The state that the MOVER is in the way role is called the MOVER way state, as in Ex 77 "guò tā shēntî" (through his body) is the representative MOVER way state of "zĭdàn" (the bullet). The state that the MOVER is in the arrival role is called the MOVER arrival state, as in Ex 78 "dào chēzhàn" (at the station) is the MOVER arrival state of "huǒchē" (the train). The state that the MOVER is in the terminal role is called the MOVER terminal state, as in Ex 79 “zài Xiăo Lín jiā"(at Xiao Lin's house) is the MOVER terminal state of "tā" (his body).
(75) Mǎ zài qípán shang.
knight on chessboard surface
(马在棋盘上。/ The knight is on the chessboard.)
(76) Huǒchē cóng Shànghăi kāi chū.
train from Shanghai start
(火车从上海开出。/ The train starts from Shanghai.) 
\begin{tabular}{rlcccc} 
& & \multicolumn{4}{c}{ Huang Ziyou } \\
(77) Zĩdàn & chuān & guò & -le & tā & shēntǐ. \\
bullet & pass & through & -Pcl-finish & his & body
\end{tabular}

(子弹穿过-了他身体。/ The bullet went through him.)

(78) Huǒchē dào chēzhàn le.

train arrive-at station Pcl-finish

(火车到车站了。/ The train arrived at the station.)

(79) Tā zài Xiăo Lín jiā.

he at Xiao Lin house

(他在小林家。/ He is at Xiao Lin's house.)

\subsubsection{Open ordered states}

The state that the MOVER is in the goal role is called the MOVER goal state, as in Ex 80 “xiàng biānjiè (向边界, towards the border)" is the MOVER goal state of "tā (他, his body)". The state that the MOVER is in the orientation role is called the MOVER orientation state, as in Ex 80 “xiàng wài-tàikōng(向外太空, towards the outer space)" is the orientation role of "Yǔzhòu Yī-hào(宇宙一号, Cosmos 1)".

$\begin{array}{rrrrr}\text { (80) Tā zhèng xiàng biānjiè } & \text { zǒu } & \text { qù } \\ \text { he be-ing towards } & \text { border } & \text { walk } & \text { go }\end{array}$

(他正向边界走去。/ He was heading towards the border.)

(81) Yǔzhòu Yī-hào jiāng lìyòng tàiyangfān xiàng wài-tàikōng fêi qu.

Cosmos 1-nomber would use solar-sailing towards outer-space fly go

(宇宙一-号将利用太阳帆向外太空飞去。/ Cosmos 1 would move towards the outer space by solar sailing .)

\subsection{The multiplicity and complexity of states}

"Role-States" are the cognitive and semantic elements in an underlying structure, which often form several "Ring-Chains"(to be elaborated later), and is projected onto a corresponding complex surface sentences, e.g. in Ex 82 :

(82)Zài bàngōngshì li, bùzhăng zài wénjiàn shang qiān le zì.
in office inside, minister on document surface

(在办公室里部长在文件上签-了字。/ The Minister has signed his name on the document in the office.)

A surface structure is an abridged underlying structure. The surface structure can trigger off the cognitive process in which the speaker and hearer comprehend the whole meaning of the surface sentence, using their knowledge of the lexicon and of the syntactic relations. Ex 82 can be analyzed as follows:

"bùzhăng zài bàngōngshì li" (The Minister is in the office) is the projection of the ERGATIVE circumstance state. "wénjiàn zài bàngōngshì li" (the document is in the office) is the projection of the MOVER circumstance state. "zì zài wénjiàn shang" (the 
name is on the document) is the projection of the MOVER terminal state. The minister sits "zài bàngōngshì y̌̌zi shang" (in the chair of the office) is the projection of the MOVER mover-circumstance state. The document is put "dào bàngōngshì zhuōzi shang"(to the desk of the office), then "wénjiàn zài bàngōngshì zhuōzi shang" (the document is on the desk of the office) is the projection of the MOVER source state.

Actually, the language information is abundant in Ex 82. "bùzhăng zài bàngōngshì li" (the minister is in the office) means that "bùzhăng"sits "zài bàngōngshì li" (the minister sits in the office). "wénjiàn zài bàngōngshì li" (the document is in the office) means that the secretary brought the document into the office. "zì zài wénjiàn shang" (the name is on the document) means that the Minister has signed his name on the document, then the name appeared on the document. "bùzhăng zài bàngōngshì yǐzi shang" (the minister is in the chair of the office) means that he sits on the chair of the office."wénjiàn zài bàngōngshì zhuōzi shang" (the document is on the desk in the office) means that the secretary has put a document on the desk of the office, etc. Among them, we use the dynamic verbs "sit, bring, put, sign" which contains the complex processes of "Role-State-Ring-Chain". E.g. the dynamic "put (放, fàng)" can consist of a list of single dynamics-“Rings":

"move $\rightarrow$ scatter $\rightarrow$ furl $\rightarrow$ fix $\rightarrow$ move $\rightarrow$ scatter $\rightarrow$ move $\rightarrow$ move".

Every single dynamic - "Ring" has a simple process of the motion. Therefore, the sentence shown in Ex 82 is a very complex sentence with abundant language information.

(To be continued)

\section{References}

Huang Ziyou. 1985. On the Virtual Verb 'Yǒu'(Have). [A] Guobin Lu (editor): Theses of the Postgraduates : Fascicuteon Linguistics and Graphetics . [C] Nanjing: Jiangsu Ancient Books .

Huang Ziyou. 1994. Multiple Space-Role-State-Ring-Chain Model. [A] In Shao Jingmin (editor in chief): Thought on the Grammar in 1990s . [C] Beijing : Beijing Languages College.

Huang, Ziyou (editor in chief). 1996. Practical Course of Linguistics. [M] Chengdu : Chengdu Science and Technology University . 